\title{
解説シリーズ「複合材料の界面力学と界面特性評価・解析」 の編集に当たって
}

編集委員 香川豊（東京大学生産技術研究所）

複合材料の特性が強化素材, マトリックス, 界面の三 種類の特性に大きく依存することは言うまでもない，最 近, 界面の特性についての関心が高まり, 界面反応物の 同定や反応の機構は分析機器の発達とともに原子, 分子 というようなミクロなレベルまでがわかるようになって いる.ところが, 複合材料の特性に直接影響する界面の 力学特性に関しては, 界面での力の発生要因, 界面の存 在による力学特性の変化, その測定手法, 界面力学特性 と複合材料特性の相関関係等いまだに不明の点が多い.
このような現状を認識し，それぞれの分野の将来展望を 理解するために, 複合材料学会セミナーが「界面のメカ ニズム」という題目で 1993 年 8 月, 盛況のもとに開催さ れた。その内容は解説シリーズとして取り上げることに よりセミナーに出席されなかった方々にも広く知ってい ただけると考えられた。 そこで，セミナーのテキストを もとに加筆修正を加えていただいた原稿をもとに解説シ リーズとして揭載することにした。本解説シリーズが読 者の方々のお役に立つことを願っている.

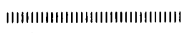

解 説

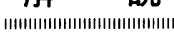

\section{複合材料の界面力学と界面特性評価 - 解析一 I. 繊維強化セラミックスの界面力学と力学特性の測定}

香川 豊*

\section{1. まえがき}

種々の複合材料の力学的特性が界面の力学的特性に依 存することは古くから知られており, 現在でも界面力学 特性の制御は複合材料工学の分野で重要な位置付けを占 めている．複合材料界面の力学特性を理解するためには 界面せん断応力が不可欠であり，種々の解析には必ず界 面せん断応力が何らかの形で導入されている.

特に, 瀻維強化セラミックスの分野では種々の特性は 界面の力学特性に大きく依存することが知られている. たとえば，破壊抵抗や累積破壊過程はマトリックスが破 壊した後に織維がクラックをブリッジすることにより達 成される。この場合，瀻維によるマトリックスのブリッ ジは纎維一マトリックス間の応力伝達機構に依存してい

* Yutaka KAGAWA：東京大学生産技術研究所（106 東京都港区六本木 7-22-1)
る.このような理由から瀻維強化セラミックスでは界面 の力学特性を正しく把握しない限り材料特性発現の機構 を理解することは難しい吕2).

繊維強化セラミックスの分野で繊維一マトリックス界 面の力学特性が重要であることが認識され出してから （i）界面の力学特性の重要性, (ii) 界面の応力伝達機 構, (iii) 界面力学特性の定量評価, などに関する研究が 数多く行われるようになった ${ }^{21}$.ここでは, 以後, 界面せ ん断応力の測定方法について著者の最近の研究をもとに 説明する。

\section{2. 界面せん断応力の取り扱い}

界面の力学特性には図 1 に示した二種類に大別され る.すなわち, (i ) 界面引つ張り特性, (ii) 界面せん断 特性, である. 後者の界面せん断特性は古くから複合材 料の力学特性に大きく影響することが知られていた. 界 